\title{
Combining ability for yield and fruit quality in the pepper Capsicum annuum
}

\author{
N.F.F. do Nascimento ${ }^{1}$, E.R. do Rêgo ${ }^{2}$, M.F. Nascimento ${ }^{1}$, C.H. Bruckner ${ }^{1}$, \\ F.L. Finger ${ }^{1}$ and M.M. do Rêgo ${ }^{2}$ \\ ${ }^{1}$ Laboratório de Análises de Progênies, Departamento de Fitotecnia, \\ Pós-Graduação em Genética e Melhoramento, Centro de Ciências Agrárias, \\ Universidade Federal de Viçosa, Viçosa, Minas Gerais, Brasil \\ ${ }^{2}$ Laboratório de Biotecnologia Vegetal, Centro de Ciências Agrárias, \\ Universidade Federal da Paraíba, Areia, PB, Brasil \\ Corresponding author: E.R. do Rêgo \\ E-mail: elizanilda@pq.cnpq.br / elizanildaramalho@hotmail.com / \\ elizanilda@cca.ufpb.br
}

Genet. Mol. Res. 13 (2): 3237-3249 (2014)

Received March 27, 2013

Accepted November 29, 2013

Published April 29, 2014

DOI http://dx.doi.org/10.4238/2014.April.29.2

\begin{abstract}
The objective of this study was to determine the effects of the general and specific combining abilities (GCA and SCA, respectively) of 15 characteristics and to evaluate the most promising crosses and the reciprocal effect between the hybrids of six parents of the Capsicum annuum species. Six parents, belonging to the Horticultural Germplasm Bank of Centro de Ciências Agrárias of Universidade Federal da Paraíba, were crossed in complete diallel manner. The 30 hybrids generated and the parents were then analyzed in a completely randomized design with three replicates. The data were submitted to analysis of variance at $1 \%$ probability, and the means were grouped by the Scott-Knott test at 1\% probability. The diallel analysis was performed according to the Griffing method, model I and fixed model. Both additive and non-additive effects influenced the hybrids' performance, as indicated by the GCA/SCA ratio. The nonadditive effects, epistasis and/or dominance, played a more important
\end{abstract}


role than the additive effects in pedicel length, pericarp thickness, fresh matter, dry matter content, seed yield per fruit, fruit yield per plant, days to fructification, and total soluble solids. The GCA effects were more important than the SCA effects in the fruit weight, fruit length and diameter, placenta length, yield, vitamin $\mathrm{C}$, and titratable acidity characteristics. The results found here clearly show that ornamental pepper varieties can be developed through hybridization in breeding programs with $C$. annuum.

Key words: General combining ability; Specific combining ability; Chili; Additive effect; Non-additive effect

\section{INTRODUCTION}

Capsicum annuum L. is the most cultivated species of its genus and shows great variability, encompassing bell peppers, paprika, spicy peppers (such as jalapeño, cayenne, serrano, and cherry), and ornamental cultivars (Casali and Couto, 1984; Rêgo et al., 2012).

Pepper plants have been standing out by their growing acceptance in the consumer market, making a difference in the variety of products that are present in nurseries and flower shops; some characteristics such as fruit color and plant build are very important, and short plants with erect, colorful, and upright fruit are preferred.

Despite the increase in cultivation and commercialization of pepper in the last few years (Rêgo et al., 2011b), there is a growing demand in Brazil for new cultivars that present higher quality, yield, and resistance to plagues, all of which can be achieved through breeding programs.

Studies on genetic divergence among individuals and populations in plant species have been greatly important in breeding programs involving hybridization because they offer parameters for identifying parents that enable a greater heterotic effect in the progeny and a higher probability of obtaining superior genotypes in segregating generations (Sudré et al., 2005; Rêgo et al., 2011b). According to Nascimento et al. (2012), genetic diversity is a criterion that is used to select parents in the production of hybrids. Pickersgill (1997) and Rêgo et al. (2011a) emphasize that the genetic variability that is available within domesticated Capsicum species has been studied little and has not yet been exhausted.

Diallel crossing stands out for promoting estimative parameters that are useful in parent selection for hybridization and in understanding the genetic effects involved in trait determination (Cruz and Regazzi, 2001; Gonçalves et al., 2011; Rêgo et al., 2011b). Nascimento et al. (2012) stated that there are few developed studies on the combining ability of fruit and yield traits in ornamental pepper.

From this perspective, the objective of this paper was to estimate the general combining ability (GCA), specific combining ability (SCA), and reciprocal effects using 15 quantitative characteristics and to determine the most promising crosses among six parents as a first step in a pepper breeding program (C. annuиm).

\section{MATERIAL AND METHODS}

The experiment was conducted in the Vegetable Biotechnology sector of Centro de Ciências Agrárias, Universidade Federal da Paraíba (CCA-UFPB), Paraíba State, Brazil. In 
this location, six pepper lines belonging to the germplasm bank of CCA-UFPB (UFPB 01, UFPB 77.1, UFPB 77.2, UFPB 132, UFPB 134, and UFPB 137) (Table 1) were used as parents and crossed in a complete diallel manner, forming a generation of 30 hybrids.

Table 1. Description of some qualitative traits of the six pepper accessions (Capsicum annuum) used in this study.

\begin{tabular}{lllllllll}
\hline Genotypes & \multicolumn{7}{c}{ Characteristics } \\
\cline { 2 - 7 } & PGH & LC & CC & FP & IFC & MFC & FS & PWF \\
\hline 01 & Intermediate & Dark green & White & Erect & Black & Red & Almost round & Intermediate \\
77.1 & Erect & Light green & White & Erect & Orange & Red & Triangle & Intermediate \\
77.2 & Erect & Green & Purple & Erect & Red & Red & Triangle & Intermediate \\
132 & Erect & Light green & Purple with white base & Erect & Orange and brown & Red & Elongate & Slight \\
134 & Intermediate & Dark green & White & Erect & Yellow & Orange & Triangle & Persistent \\
137 & Erect & Green & White & Erect & Light brown & Orange & Triangle & Persistent \\
\hline
\end{tabular}

$\mathrm{PGH}=$ plant growth habit; $\mathrm{LC}=$ leaf color; $\mathrm{CC}=$ corolla color; $\mathrm{FP}=$ fruit position; $\mathrm{IFC}=$ fruit color at intermediate stage; $\mathrm{MFC}=$ fruit color at mature stage; $\mathrm{FS}=$ fruit shape; $\mathrm{PWF}=$ persistence pedicel with fruit.

The parents and their progeny were sowed in a polystyrene tray with 200 cells. The plants were transplanted after showing six definitive leaves and were cultivated in a $1300-\mathrm{mL}$ plastic pot filled with commercial substrate (Plantmax, Brazil).

Of the 15 traits studied, 10 referred to yield and five to fruit quality. The characteristics that were evaluated for yield included the following: fruit weight, fruit length, fruit diameter, pedicel length, pericarp thickness, fresh fruit matter, seed yield per fruit, fruit yield per plant, yield, and days to fructification. The fruit quality characteristics that were evaluated were placenta length, dry matter content of the fruit, vitamin $\mathrm{C}$, titrable acidity, and total soluble solids. All characteristics were based on the list of descriptors suggested by the International Plant Genetic Resources Institute (1995).

A completely randomized design was used with 36 treatments (parents and hybrids) in three repetitions. The data were subjected to analysis of variance, and then the means were grouped by the Scott-Knott method at $1 \%$ probability. The diallel analysis was performed by the Griffing method (1956), model I and fixed model; from this, the GCA and SCA estimates were obtained.

The following statistical model was used: $Y i j=m+g i+g j+s i j+r i j+e i j$, where $Y i j$ is the mean of the hybrid combination $(i \neq j)$ or parent combination $(i=j) ; m$ is the general mean; $g i$ and $g j$ are the GCA values of the $i$ th and $j$ th parents, respectively $(i, j=1,2, \ldots, p)$; $s i j$ is the SCA effects for the crosses between the $i$ th and $j$ th parents; rij is the reciprocal effect that measures the differences made by parent $i$ or $j$ when used as male or female in the $i j$ cross; $e i j$ is the average experimental error associated with the observation of the $i j k$ order $(\mathrm{k}=1, \ldots$ $., r)$, where $r$ is the number of repetitions.

To evaluate the significant differences between GCA, SCA, and reciprocal effect, an F-test was utilized. The comparison between $g i$, sij, and $r i j$ was made by a $t$-test. All statistical analyses were performed using the Genes computer software (Cruz, 2006).

\section{RESULTS AND DISCUSSION}

Significant variation was observed in the fruit quality and yield traits, except pericarp thickness, among parents and hybrids (Table 2) according to the Skott-Knott grouping at 1\% 
probability. The fruit diameter, pedicel length, seed yield per fruit, and vitamin $\mathrm{C}$ characteristics formed two groups. The genotypes were separated in three groups for fruit weight, placenta length, fresh matter, and dry matter content. The fruit length and total soluble solid characteristics formed four groups. Six groups were formed for the titratable acidity and days to fructification traits. For the fruit yield per plant and yield characteristics, the accessions and hybrids formed five and eight groups, respectively (Table 2). These results proved to be of great variability among the genotypes. Similar results were reported by Rêgo et al. (2009a).

\begin{tabular}{|c|c|c|c|c|c|c|c|c|c|c|c|c|c|c|c|}
\hline Accessions & FW & FL & FD & PL & PT & PLL & FFM & DMC & SYF & FYP & DTF & $\mathrm{Y}$ & VITC & TA & TSS \\
\hline 01 & $0.22^{\mathrm{c}}$ & $0.87^{\mathrm{d}}$ & $0.66^{\mathrm{b}}$ & $1.59^{b}$ & $0.11^{\mathrm{a}}$ & $0.52^{\mathrm{c}}$ & $0.16^{\mathrm{c}}$ & $19.12^{\mathrm{b}}$ & $17.66^{\mathrm{b}}$ & $20.00^{\mathrm{d}}$ & $8000 \mathrm{~d}$ & $4.39^{b}$ & & $19.17^{d}$ & $7.26^{\mathrm{c}}$ \\
\hline $01 \times 77.1$ & $51^{\mathrm{c}}$ & $1.52^{\mathrm{d}}$ & $72^{b}$ & $1.94^{\mathrm{b}}$ & & & & & & & & & & & $7.60^{\mathrm{b}}$ \\
\hline $01 \times 77.2$ & $0.33^{\mathrm{c}}$ & $1.20^{\mathrm{d}}$ & $.70^{\mathrm{b}}$ & $1.46^{\mathrm{b}}$ & $0.12^{\mathrm{a}}$ & & & $21.06^{\mathrm{b}}$ & $22.66^{\mathrm{b}}$ & & & & & & $8.10^{\mathrm{b}}$ \\
\hline $1 \times 132$ & $1.17^{\mathrm{b}}$ & $3.46^{\mathrm{a}}$ & $0.79^{\mathrm{b}}$ & $2.27^{\mathrm{a}}$ & $0.12^{\mathrm{a}}$ & $1.64^{\mathrm{b}}$ & $0.88^{\mathrm{b}}$ & $15.05^{\mathrm{c}}$ & $43.66^{a}$ & $0^{c}$ & $0^{\mathrm{d}}$ & & & & $8.93^{\mathrm{a}}$ \\
\hline 1 x 134 & $.73^{\mathrm{c}}$ & $1.54^{\mathrm{d}}$ & $.81^{\mathrm{b}}$ & $2.38^{\mathrm{a}}$ & $0.10^{\mathrm{a}}$ & & & $26.03^{\mathrm{a}}$ & $38.66^{\mathrm{a}}$ & $0^{\mathrm{d}}$ & & & & & $7.00^{c}$ \\
\hline x 137 & $93^{\mathrm{b}}$ & $1.69^{c}$ & $1.06^{\mathrm{a}}$ & $2.05^{\mathrm{b}}$ & $0.14^{\mathrm{a}}$ & & & $14.02^{c}$ & $43.66^{\mathrm{a}}$ & & & & & & $7.96^{\mathrm{b}}$ \\
\hline 77.1 x 01 & $0.48^{\mathrm{c}}$ & $1.16^{\mathrm{d}}$ & $0.82^{\mathrm{b}}$ & $2.39^{\mathrm{a}}$ & $0.14^{\mathrm{a}}$ & $0.90^{\mathrm{c}}$ & $0.33^{\mathrm{c}}$ & $17.26^{\mathrm{c}}$ & $37.66^{\mathrm{a}}$ & $0^{\mathrm{c}}$ & & $12.91^{\mathrm{b}}$ & & & $8.70^{\mathrm{a}}$ \\
\hline 77.1 & $0.34^{\mathrm{c}}$ & $1.15^{\mathrm{d}}$ & $0.66^{\mathrm{b}}$ & $2.12^{\mathrm{b}}$ & $0.11^{\mathrm{a}}$ & $0.51^{\mathrm{c}}$ & $0.25^{\mathrm{c}}$ & $27.86^{\mathrm{a}}$ & $21.33^{b}$ & $20.00^{\mathrm{d}}$ & & & & & $6.66^{c}$ \\
\hline $77.1 \times 77.2$ & $0.51^{\mathrm{c}}$ & $1.06^{\mathrm{d}}$ & $0.83^{\mathrm{a}}$ & $2.53^{\mathrm{a}}$ & $0.12^{\mathrm{a}}$ & $0.60^{\mathrm{c}}$ & $0.31^{\mathrm{c}}$ & $16.13^{\mathrm{c}}$ & $34.33^{\mathrm{a}}$ & $30.00^{\mathrm{b}}$ & $90.00^{d}$ & $7.87^{\mathrm{b}}$ & & & $5.50^{\mathrm{d}}$ \\
\hline 77.1 x 132 & $0.73^{\mathrm{c}}$ & $2.80^{\mathrm{b}}$ & $0.66^{\mathrm{b}}$ & $2.42^{\mathrm{a}}$ & $0.10^{\mathrm{a}}$ & $1.51^{\mathrm{b}}$ & $0.52^{\mathrm{c}}$ & $18.58^{\mathrm{b}}$ & $35.66^{\mathrm{a}}$ & $25.00^{c}$ & $92.00^{c}$ & $19.05^{\mathrm{b}}$ & & & $4.66^{\mathrm{d}}$ \\
\hline $77.1 \times 134$ & $0.41^{\mathrm{c}}$ & $1.50^{\mathrm{d}}$ & $0.66^{\mathrm{b}}$ & $1.66^{\mathrm{b}}$ & $0.12^{\mathrm{a}}$ & $0.91^{\mathrm{c}}$ & $0.27^{\mathrm{c}}$ & $18.23^{\mathrm{b}}$ & $27.00^{\mathrm{b}}$ & $20.00^{\mathrm{d}}$ & $95.00^{\mathrm{b}}$ & $20.36^{\mathrm{b}}$ & $59.50^{\mathrm{a}}$ & & $5.76^{\mathrm{d}}$ \\
\hline $77.1 \times 137$ & $0.80^{\mathrm{c}}$ & $1.89^{\mathrm{c}}$ & $0.86^{\mathrm{a}}$ & $2.06^{\mathrm{b}}$ & $0.13^{\mathrm{a}}$ & $1.22^{\mathrm{c}}$ & $0.56^{\mathrm{c}}$ & $10.54^{c}$ & $50.66^{\mathrm{a}}$ & & & $22.47^{\mathrm{a}}$ & & & $6.16^{\mathrm{c}}$ \\
\hline $77.2 \times 01$ & $0.52^{\mathrm{c}}$ & $1.14^{\mathrm{b}}$ & $0.85^{\mathrm{a}}$ & $1.63^{\mathrm{b}}$ & 0.1 & & & $3.95^{\mathrm{c}}$ & 42.3 & & & & & & $7.86^{\mathrm{b}}$ \\
\hline $77.2 \times 77.1$ & $0.26^{\mathrm{c}}$ & $1.11^{\mathrm{d}}$ & & & & & & $19.91^{\mathrm{b}}$ & & & & & & & $6.60^{\mathrm{c}}$ \\
\hline 77.2 & & $1.04^{\mathrm{d}}$ & $0.58^{\mathrm{b}}$ & & & & & & & & & & & & $7.66^{\mathrm{b}}$ \\
\hline $77.2 \times 132$ & & $1.80^{\mathrm{c}}$ & $0.64^{\mathrm{b}}$ & & & & & & & & & & & & $7.90^{\mathrm{b}}$ \\
\hline $77.2 \mathrm{x}$ & $0.39^{\mathrm{c}}$ & $1.48^{\mathrm{d}}$ & $0.76^{\mathrm{b}}$ & $2.58^{\mathrm{a}}$ & 0.1 & & & & 13. & & & & & & $8.66^{\mathrm{a}}$ \\
\hline $77.2 \times 137$ & $0.46^{\mathrm{c}}$ & $1.46^{\mathrm{d}}$ & $0.65^{\mathrm{b}}$ & $1.40^{\mathrm{b}}$ & 0.0 & & 0.2 & $10.51^{\mathrm{c}}$ & 30. & & & & & & $9.06^{\mathrm{a}}$ \\
\hline 132 x 01 & $1.43^{\mathrm{b}}$ & $3.53^{\mathrm{a}}$ & $0.88^{\mathrm{a}}$ & $2.02^{\mathrm{b}}$ & $0.12^{\mathrm{a}}$ & $1.79^{\mathrm{b}}$ & & $22.87^{b}$ & $47.33^{\mathrm{a}}$ & & & & & & $9.63^{\mathrm{a}}$ \\
\hline $132 \times 77.1$ & $0.76^{\mathrm{c}}$ & $2.39^{\mathrm{b}}$ & $0.77^{\mathrm{b}}$ & $1.67^{\mathrm{b}}$ & $0.11^{\mathrm{a}}$ & $1.35^{\mathrm{c}}$ & $0.49^{\mathrm{c}}$ & $19.49^{\mathrm{b}}$ & $43.66^{\mathrm{a}}$ & $32.00^{\mathrm{b}}$ & $93.00^{c}$ & $18.30^{\mathrm{b}}$ & $8.80^{\mathrm{b}}$ & $2.81^{\mathrm{e}}$ & $4.83^{\mathrm{d}}$ \\
\hline $132 \times 77.2$ & $1.03^{\mathrm{b}}$ & $3.24^{\mathrm{a}}$ & $0.73^{b}$ & $2.41^{\mathrm{a}}$ & $0.11^{\mathrm{a}}$ & $1.65^{\mathrm{b}}$ & $0.77^{\mathrm{b}}$ & $18.15^{\mathrm{b}}$ & $34.00^{\mathrm{a}}$ & $15.00^{\mathrm{e}}$ & $90.00^{\mathrm{d}}$ & $15.31^{\mathrm{b}}$ & $8.38^{\mathrm{b}}$ & & $7.00^{c}$ \\
\hline 132 & $1.37^{\mathrm{b}}$ & $3.84^{\mathrm{a}}$ & $0.66^{\mathrm{b}}$ & $2.30^{\mathrm{a}}$ & $0.15^{\mathrm{a}}$ & $3.25^{\mathrm{a}}$ & $1.18^{\mathrm{a}}$ & $15.45^{\mathrm{c}}$ & $16.33^{b}$ & & $95.00^{\mathrm{b}}$ & $20.40^{\mathrm{b}}$ & $8.00^{\mathrm{b}}$ & $2.56^{\mathrm{e}}$ & $6.66^{\mathrm{c}}$ \\
\hline $132 \times 134$ & $0.83^{\mathrm{c}}$ & $2.89^{\mathrm{b}}$ & $0.75^{\mathrm{b}}$ & $2.05^{\mathrm{b}}$ & $0.13^{\mathrm{a}}$ & $1.61^{\mathrm{b}}$ & $0.65^{\mathrm{c}}$ & $15.95^{\mathrm{c}}$ & $36.00^{\mathrm{a}}$ & $20.00^{\mathrm{d}}$ & & & $7.65^{\mathrm{b}}$ & & $7.70^{\mathrm{b}}$ \\
\hline $132 \times 137$ & $1.59^{\mathrm{a}}$ & $3.52^{\mathrm{a}}$ & $0.90^{\mathrm{a}}$ & $3.08^{\mathrm{a}}$ & $0.13^{\mathrm{a}}$ & $1.74^{\mathrm{b}}$ & $1.25^{\mathrm{a}}$ & $15.91^{\mathrm{c}}$ & $43.33^{\mathrm{a}}$ & $18.00^{\mathrm{e}}$ & $92.00^{c}$ & $25.07^{\mathrm{a}}$ & $7.33^{\mathrm{b}}$ & $2.34^{\mathrm{f}}$ & $7.73^{b}$ \\
\hline 134 x 01 & $0.73^{\mathrm{c}}$ & $1.41^{\mathrm{d}}$ & $0.96^{\mathrm{a}}$ & $2.18^{\mathrm{a}}$ & $0.13^{\mathrm{a}}$ & $0.78^{c}$ & & & $41.66^{\mathrm{a}}$ & & & $14.58^{b}$ & $7.04^{\mathrm{b}}$ & $2.25^{\mathrm{f}}$ & $9.60^{\mathrm{a}}$ \\
\hline 134 x 77.1 & $1.01^{\mathrm{b}}$ & $2.06^{\mathrm{c}}$ & & $2.94^{\mathrm{a}}$ & & & & & & & & & & & $9.53^{\mathrm{a}}$ \\
\hline $134 \times 77.2$ & & & & & & & & & & & & & & & $9.86^{\mathrm{a}}$ \\
\hline $134 \times 132$ & & & & & & & & & & & & & & & $8.83^{\mathrm{a}}$ \\
\hline 134 & & $2.47^{b}$ & & & & & & & & & & & & & $7.50^{\mathrm{b}}$ \\
\hline $134 \times 137$ & $2.07^{\mathrm{a}}$ & $2.69^{b}$ & $1.04^{\mathrm{a}}$ & $1.75^{\mathrm{b}}$ & & $1.28^{\mathrm{c}}$ & & & & & & & $5.87^{\mathrm{b}}$ & & $8.43^{\mathrm{b}}$ \\
\hline 137 x 01 & $1.32^{\mathrm{b}}$ & $2.64^{b}$ & $1.01^{\mathrm{a}}$ & $2.14^{b}$ & $0.11^{\mathrm{a}}$ & $1.16^{\mathrm{c}}$ & $1.04^{\mathrm{a}}$ & $17.55^{\mathrm{b}}$ & $45.66^{\mathrm{a}}$ & $25.00^{c}$ & $81.00^{\mathrm{h}}$ & $20.12^{\mathrm{b}}$ & $5.68^{\mathrm{b}}$ & $1.81^{\mathrm{f}}$ & $9.03^{\mathrm{a}}$ \\
\hline $137 \times 77.1$ & $1.12^{\mathrm{b}}$ & $2.13^{\mathrm{c}}$ & $0.97^{\mathrm{a}}$ & $1.97^{\mathrm{b}}$ & $0.14^{\mathrm{a}}$ & $1.19^{\mathrm{c}}$ & $0.78^{\mathrm{b}}$ & $12.86^{\mathrm{c}}$ & $50.66^{\mathrm{a}}$ & $20.00^{\mathrm{d}}$ & $93.00^{c}$ & $14.38^{\mathrm{b}}$ & $5.50^{\mathrm{b}}$ & $1.76^{\mathrm{f}}$ & $7.00^{\mathrm{c}}$ \\
\hline $137 \times 77.2$ & $1.15^{\mathrm{b}}$ & $2.21^{\mathrm{c}}$ & $1.04^{\mathrm{a}}$ & $1.97^{\mathrm{b}}$ & $0.13^{\mathrm{a}}$ & $1.02^{\mathrm{c}}$ & $0.87^{\mathrm{b}}$ & $20.65^{b}$ & $40.66^{a}$ & $20.00^{\mathrm{d}}$ & $93.00^{c}$ & $10.61^{\mathrm{b}}$ & $5.33^{\mathrm{b}}$ & $1.70^{\mathrm{f}}$ & $7.13^{\mathrm{c}}$ \\
\hline $137 \times 132$ & $1.12^{\mathrm{b}}$ & $2.63^{\mathrm{b}}$ & $0.67^{\mathrm{b}}$ & $2.52^{\mathrm{a}}$ & $0.11^{\mathrm{a}}$ & $1.12^{\mathrm{c}}$ & $0.79^{\mathrm{b}}$ & $14.09^{\mathrm{b}}$ & $31.66^{\mathrm{b}}$ & $22.00^{\mathrm{d}}$ & $92.00^{c}$ & $28.54^{\mathrm{a}}$ & $5.18^{\mathrm{b}}$ & $1.65^{\mathrm{f}}$ & $7.73^{\mathrm{b}}$ \\
\hline $137 \times 134$ & $1.24^{\mathrm{b}}$ & $2.14^{\mathrm{c}}$ & $1.04^{\mathrm{a}}$ & $2.65^{\mathrm{a}}$ & $0.13^{\mathrm{a}}$ & $0.88^{\mathrm{c}}$ & $0.86^{\mathrm{b}}$ & $20.13^{b}$ & $25.66^{\mathrm{b}}$ & $25.00^{c}$ & $91.00^{\mathrm{d}}$ & $34.64^{\mathrm{a}}$ & $5.03^{\mathrm{b}}$ & $1.61^{\mathrm{f}}$ & $5.46^{\mathrm{d}}$ \\
\hline 137 & $1.18^{\mathrm{b}}$ & $2.18^{\mathrm{c}}$ & $0.94^{\mathrm{a}}$ & $2.02^{\mathrm{b}}$ & $0.12^{\mathrm{a}}$ & $0.91^{\mathrm{c}}$ & $0.97^{\mathrm{b}}$ & $18.56^{\mathrm{b}}$ & $32.00^{\mathrm{b}}$ & $20.00^{\mathrm{d}}$ & $96.00^{\mathrm{a}}$ & $23.65^{\mathrm{a}}$ & $4.89^{\mathrm{b}}$ & $1.56^{\mathrm{f}}$ & $6.83^{\mathrm{c}}$ \\
\hline
\end{tabular}

$\mathrm{FW}=$ fruit weight $(\mathrm{g}) ; \mathrm{FL}=$ fruit length $(\mathrm{cm}) ; \mathrm{FD}=$ fruit diameter $(\mathrm{cm}) ; \mathrm{PL}=$ pedicel length $(\mathrm{cm}) ; \mathrm{PT}=$ pericarp thickness $(\mathrm{cm}) ;$ PLL $=$ placenta length $(\mathrm{cm}) ; \mathrm{FFM}=$ fresh fruit matter $(\mathrm{g}) ; \mathrm{DMC}=$ dry matter content $(\mathrm{g}) ; \mathrm{SYF}$ $=$ seed yield per fruit; FYP = fruit yield per plant; DTF = days to fructification; $\mathrm{Y}=$ yield ( $\mathrm{g} /$ per plant); VITC = vitamin $\mathrm{C}(\mathrm{mg}$ ascorbic acid/100 g); TA = titratable acidity ( $\mathrm{g}$ citric acid/100 $\mathrm{g}$ fresh fruit); $\mathrm{TSS}=$ total soluble solids ( ${ }^{\circ}$ Brix). Equal letters in columns do not differ statistically by the Scott-Knott test at $1 \%$ probability.

The average performance of parents and hybrids is listed in Table 2. Some hybrids were superior for the following traits: fruit weight $(134 \times 132,134 \times 137$, and $132 \times 137)$, fruit length (132 x 01 and $132 \times 137)$, dry matter content ( $01 \times 134)$, fresh matter $(132 \times 01,132 \times$ $137,134 \times 132,134 \times 137$, and 137 x 01), fruit yield per plant (77.2 x 134), yield (01 x 132, 
$01 \times 137$, and $134 \times 137)$, vitamin C (77.2 x 77.1), and titratable acidity (77.2 x 77.1). These are the combinations that are indicated for obtaining high yield per plant and high nutritional quality. If, however, the goal is to obtain early plants, the interesting combinations are that they had the lowest days to maturing value $(01 \times 77.1$ and $137 \times 01)$.

The mean square significance related to GCA $(g i)(\mathrm{P} \leq 0.01)$ was observed in all evaluated traits. The mean squares referring to SCA $(s i j)$ were significant at the $5 \%$ probability level for the fruit diameter and weight, pericarp thickness, and fresh matter characteristics; for the other variables, significance was observed at the $1 \%$ level. Reciprocal effects $(\mathrm{P} \leq 0.01)$ were also detected for all evaluated characteristics except pericarp thickness, placenta length, and seed yield per fruit (Table 3). Rêgo et al. (2009a) also found reciprocal effects for these same traits through diallel analysis in Capsicum baccatum.

\begin{tabular}{|c|c|c|c|c|c|c|c|c|}
\hline SV & GCA & SCA & Reciprocal & Error & $\hat{\Phi}^{2} g$ & $\hat{\Phi}^{2} s$ & $\hat{\Phi}_{r e}^{2}$ & $\hat{\Phi}^{2} g / \hat{\Phi}^{2} s$ \\
\hline d.f. & 5 & 15 & 15 & 62 & - & - & - & - \\
\hline FW & $2.93 * *$ & $0.17 \mathrm{~ns}$ & $0.33 \mathrm{~ns}$ & 0.08 & 0.07 & 0.02 & 0.04 & 2.72 \\
\hline FL & $11.75^{* *}$ & $0.44 * *$ & $0.53 * *$ & 0.13 & 0.32 & 0.1 & 0.06 & 3.11 \\
\hline FD & $0.19 * *$ & $0.02 *$ & $0.04 * *$ & 0.01 & 0.005 & 0.004 & 0.004 & 1.27 \\
\hline PL & $0.64^{* *}$ & $0.43^{* *}$ & $0.42 * *$ & 0.009 & 0.01 & 0.11 & 0.05 & 0.1358 \\
\hline PT & $0.002 * *$ & $0.001 *$ & $0.0007 \mathrm{~ns}$ & 0.0004 & 0.00004 & 0.0001 & 0.00003 & 0.4 \\
\hline PLL & $4.18^{* *}$ & $0.28 * *$ & $0.13 \mathrm{~ns}$ & 0.09 & 0.11 & 0.06 & 0.007 & 1.77 \\
\hline FFM & $1.88^{* *}$ & $0.08^{*}$ & $0.20 * *$ & 0.04 & 0.05 & 0.01 & 0.02 & 0.04 \\
\hline DMC & $204.36^{* *}$ & $156.82^{* *}$ & $72.91 * *$ & 36.88 & 4.65 & 39.98 & 6 & 0.11 \\
\hline SYF & $687.94 * *$ & $425.80^{* *}$ & $213.83 \mathrm{~ns}$ & 129.42 & 15.51 & 98.79 & 14.06 & 0.15 \\
\hline FYP & $158.62 * *$ & $65.58^{* *}$ & $62.91^{* *}$ & 1.64 & 4.36 & 21.31 & 10.21 & 0.2 \\
\hline DTF & $220.16^{* *}$ & $52.93 * *$ & $4.80^{* *}$ & 1 & 6.08 & 17.31 & 0.63 & 0.35 \\
\hline Y & $815.87 * *$ & $134.45^{* *}$ & $77.41 *$ & 37.26 & 21.62 & 32.39 & 6.69 & 1.72 \\
\hline Vit C & $8885.42 * *$ & $432.92 * *$ & $1765.48^{* *}$ & 1 & 246.78 & 143.97 & 294.08 & 1.71 \\
\hline TA & $907.21 * *$ & $43.26^{* *}$ & $180.21^{* *}$ & 1 & 25.17 & 14.08 & 29.86 & 1.78 \\
\hline TSS & $11.43^{* *}$ & $4.70^{* * *}$ & $4.414 * *$ & 1 & 0.28 & 1.23 & 0.53 & 0.23 \\
\hline
\end{tabular}

$\mathrm{SV}=$ source of variation; d.f. $=$ Degrees of freedom; $\mathrm{FW}=$ fruit weight $(\mathrm{g}) ; \mathrm{FL}=$ fruit length $(\mathrm{cm}) ; \mathrm{FD}=$ fruit diameter $(\mathrm{cm}) ; \mathrm{PL}=$ pedicel length $(\mathrm{cm}) ; \mathrm{PT}=$ pericarp thickness $(\mathrm{cm}) ; \mathrm{PLL}=$ placenta length $(\mathrm{cm}) ; \mathrm{FFM}=$ fresh fruit matter $(\mathrm{g}) ; \mathrm{DMC}=$ dry matter content $(\mathrm{g}) ; \mathrm{SYF}=$ seed yield per fruit; FYP = fruit yield per plant; DTF = days to fructification; $\mathrm{Y}=$ yield $(\mathrm{g})$; Vit $\mathrm{C}=$ vitamin $\mathrm{C}(\mathrm{mg}$ ascorbic acid $/ 100 \mathrm{~g}) ; \mathrm{TA}=$ titratable acidity $(\mathrm{g}$ citric acid $/ 100$ $\mathrm{g}$ fresh fruit); TSS $=$ total soluble solids $\left({ }^{\circ}\right.$ Brix $) . * *$ Significant at $1 \%$ probability; $*$ significant at $5 \%$ probability by the F-test; ns = not significant.

Additive and non-additive effects influenced the hybrids' performance, as indicated by the GCA/SCA ratio (Table 3). The highest $\hat{\Phi}^{2} s$ value indicates that non-additive effects, epistasis and/or dominance, played a more significant role than additive effects in the pericarp thickness, fresh matter, dry matter content, seed yield per fruit, pedicel length, fruit yield per plant, days to fructification, and total soluble solids (Table 3 ). The $\hat{\Phi}^{2} g$ values were more important to the following variables: fruit length, diameter, and weight; placenta length, yield, vitamin $\mathrm{C}$, and titratable acidity (Table 3). This indicates that additive gene action was predominant in the control of these characteristics. Similar results were obtained by Geleta and Labuschagne (2004a) and Rêgo et al. (2009a). 


\section{Yield characteristics}

The additive effects (GCA) and non-additive effects (SCA) were significant at $1 \%$ probability in the F-test for all evaluated traits. Reciprocal effects $(\mathrm{P} \leq 0.01)$ were also detected for all evaluated characteristics except pericarp thickness and seed yield per fruit. According to Rêgo et al. (2009a), the significant differences in reciprocal effect variations imply that maternal effects are important in C. baccatum.

The variance magnitude due to $\operatorname{SCA}\left(\hat{\phi}_{s}^{2}\right)$ was higher than that due to $\operatorname{GCA}\left(\hat{\phi}_{g}^{2}\right)$ for all of the yield characteristics evaluated except yield and fruit length, diameter, and weight, indicating the importance of non-additive gene action, epistasis and/or dominance, to the determination of the evaluated traits (Table 3 ). These results were also corroborated by the $\hat{\phi}_{g}^{2} / \hat{\phi}_{s}^{2}$ ratio (Table 3 ).

In relation to genetic component estimates, additive gene effects were observed for the fruit weight variable. Similar results were reported by Ahmed et al. (1997), Ben-Chaim and Paran (2000), Geleta and Labuschagne (2004a,b), Kamble et al. (2009), and Marame et al. (2009). On the other hand, Patel et al. (1988), Doshi and Shukla (2000), Zambrano et al. (2005), and Reddy et al. (2008) observed that non-additive effects, epistasis and/or dominance, influence this trait.

The highest GCA $\left(\hat{\phi}_{g}^{2}\right)$ value for the fruit diameter and length traits indicates the predominance of additive gene effects in the control of these characteristics. Previous studies have shown that these characteristics were governed by genes acting additively (Ben-Chaim and Paran, 2000; Zewdie and Bosland, 2000; Geleta and Labuschagne, 2004a; Zambrano et al., 2005; Gomide et al., 2008; Rêgo et al., 2009a).

Additive gene effects were also identified in this study for the yield variable. In pepper, previous reports have shown that this character can be governed by either additive effects (Patel et al., 1988; Zambrano et al., 2005) or by non-additive effects (Ahmed et al., 1997; Doshi and Shukla, 2000; Rêgo et al., 2009a). Because of the significant additive effect reported in this study, an effective increase or decrease in these traits can be achieved through successive generations of backcrossing and selection of desired recombinants from segregating populations or even through recurrent selection, thus increasing the frequency of favorable alleles for these characteristics (Rêgo et al., 2009a).

The highest SCA $\left(\hat{\phi}_{s}^{2}\right)$ value was important for the pericarp thickness trait, indicating non-additive gene effects, epistasis and/or dominance, in its determination. Similar results were obtained by Ben-Chaim and Paran (2000) and Zewdie and Bosland (2001) in studies with C. annuum and C. pubescens, respectively, and in pepper by Reddy et al., (2008). These results diverge from those observed by Geleta and Labuschagne (2004a) and Rêgo et al. (2009a), who also reported the presence of reciprocal effects that were not observed in this study.

Non-additive gene action, epistasis and/or dominance, was observed in the pedicel length characteristic. This result agrees with that from the report by Reddy et al. (2008), who evaluated combining ability in $C$. annuиm.

A greater magnitude of non-additive effects, epistasis and/or dominance, was also observed in this study for the fresh matter trait. Contrary to the findings of Marin and Lippert (1975), Ahmed et al. (1999), Geleta and Labuschagne (2004a), and Rêgo et al. (2009a), whose researchs with pepper showed that a greater magnitude of additive effects controlled the characteristic.

Regarding seed yield per fruit and fruit yield per plant, predominantly non-additive gene actions influenced the traits. Similar results were reported by Reddy et al. (2008) and Kamble et al. (2009). However, most research indicated that predominantly additive gene actions controlled these characteristics both in pepper (Doshi and Shukla, 2000; Somashekhar 
and Salimath, 2008) and in chili (Marin and Lippert, 1975; Patel et al., 1988; Ahmed et al., 1997; Geleta and Labuschagne, 2004a; Rêgo et al., 2009a).

The non-additive effects also contributed more to the days to fructification characteristic than additive effects, a result that was previously confirmed by Ahmed et al. (1997) and Doshi and Shukla (2000). However, Patel et al. (1988) and Geleta and Labuschagne (2004a) reported that the predominant effects for this trait were additive in nature.

The $\hat{g} i$ estimates presented values that were significantly positive and negative for all evaluated characteristics except pericarp thickness (Table 4).

\begin{tabular}{|c|c|c|c|c|c|c|}
\hline Parents & 1 & 77.1 & 77.2 & 132 & 134 & 137 \\
\hline FW & -0.15 & $-0.25^{*}$ & $-0.34 *$ & $0.27^{*}$ & 0.16 & $0.31 *$ \\
\hline FL & $-0.31 *$ & $-0.40^{*}$ & $-0.54^{*}$ & $1.01 *$ & 0.03 & 0.21 \\
\hline $\mathrm{FD}$ & 0.007 & -0.04 & -0.07 & -0.06 & 0.06 & $0.10^{*}$ \\
\hline PL & $-0.20^{*}$ & 0.01 & -0.06 & 0.15 & 0.13 & -0.03 \\
\hline PT & 0 & 0 & -0.01 & 0.0007 & 0.01 & 0.001 \\
\hline PLL & -0.17 & -0.17 & $-0.27^{*}$ & $0.66^{*}$ & 0 & -0.03 \\
\hline FFM & -0.11 & $-0.20^{*}$ & $-0.27 *$ & $0.25^{*}$ & 0.08 & $0.24 *$ \\
\hline DMC & 0.87 & $1.89^{*}$ & $-3.27 *$ & $-1.44 *$ & $3.13 *$ & $-1.18^{*}$ \\
\hline SYF & 1.23 & 0.39 & $-7.99 *$ & -0.74 & 2.09 & 5 \\
\hline FYP & 0.28 & 0.39 & $3.73 *$ & $-1.93^{*}$ & $-0.51^{*}$ & $-1.96^{*}$ \\
\hline DTF & $-4.61^{*}$ & -0.61 & 0.47 & $2.22 *$ & $1.80^{*}$ & $0.72 *$ \\
\hline Y & -1.61 & $-4.82 *$ & $-5.75^{*}$ & 3.94 & 2.58 & $5.66 *$ \\
\hline Vit C & $17.02^{*}$ & $18.49^{*}$ & $5.76^{*}$ & $-13.14 *$ & $-14.17 *$ & $-13.96^{*}$ \\
\hline TA & $5.46^{*}$ & $5.90^{*}$ & $1.81 *$ & $-4.18^{*}$ & $-4.52 *$ & $-4.47^{*}$ \\
\hline TSS & 0.67 & $-0.93 *$ & 0.17 & -0.21 & 0.41 & -0.12 \\
\hline
\end{tabular}

$\mathrm{FW}=$ fruit weight $(\mathrm{g}) ; \mathrm{FL}=$ fruit length $(\mathrm{cm}) ; \mathrm{FD}=$ fruit diameter $(\mathrm{cm}) ; \mathrm{PL}=$ pedicel length $(\mathrm{cm}) ; \mathrm{PT}=$ pericarp thickness $(\mathrm{cm}) ;$ PLL $=$ placenta length $(\mathrm{cm}) ; \mathrm{FFM}=$ fresh fruit matter $(\mathrm{g}) ; \mathrm{DMC}=$ dry matter content $(\mathrm{g}) ; \mathrm{SYF}$ $=$ seed yield per fruit; FYP = fruit yield per plant; DTF = days to fructification; $\mathrm{Y}=$ yield $(\mathrm{g})$; Vit $\mathrm{C}=$ vitamin $\mathrm{C}$ $(\mathrm{mg}$ ascorbic acid/100 $\mathrm{g}) ; \mathrm{TA}=$ titratable acidity ( $\mathrm{g}$ citric acid/100 $\mathrm{g}$ fresh fruit); TSS = total soluble solids $\left({ }^{\circ}\right.$ Brix). *Significant at $5 \%$ probability by the $t$-test.

Good genitors that presented elevated absolute GCA levels should be preferred to form crossing blocks, favoring the selection of homozygotic lineages in autogamous species (Ahmed et al., 1999; Geleta and Labuschagne, 2004a; Rêgo et al., 2009a). Parents 137 and 132 showed significant positive values for fruit weight and yield, while genitors 77.1 and 77.2 had significant negative values for both traits (Table 4). The fruit weight, in addition to being a quality determinant, is an important characteristic for the yield determination in pepper plants. It is important to highlight that the average fruit weight can be altered according to the fruit yield per plant (Rêgo et al., 2009b).

The GCA estimates showed that parent 132 had a positive significant value for the fruit length trait, and parent 137 had a significant positive value for the fruit diameter characteristic; significant negative values were observed in parents $01,77.1$, and 77.2 for the fruit length characteristic only. Fruit length and diameter are of the utmost importance in peppers that are destined for fresh consumption. Casali and Couto (1984) and Heiden et al. (2007) emphasized the importance of the fruit size, which must have a width compatible with the preparation methods, either for dry or fresh pepper consumption.

Positive significant $g i$ values were observed for fresh matter in parents 132, 134, and 137. Parents 77.1 and 77.2 presented negative significant values (Table 4). Fresh matter or 
fresh weight is considered a primary component of yield (Poulos, 1994), and it is important to select plants with heavier fruits.

According to gi estimates, parent 77.2 had a significantly negative value for the seed yield per fruit trait, which is not of interest (Table 4). However, that same genitor proved to be a good parent, obtaining significantly positive values for fruit yield per plant. Seed yield per fruit and fruit yield per plant are yield components.

Based on GCA, genitor 01 can be used as parent (Table 4) to obtain premature fruits, and it can be used in crossings with the objective of reducing pedicel length. This characteristic is of the utmost importance because it can base the selection of traits that lead to reduced losses and that ease the harvest process (Heiden et al., 2007).

Genitors of interest should be used to increase the yield per plant, as well as increase or decrease fruit size. The higher the $\hat{g} i$ (GCA) effects are, either negative or positive, the more superior or inferior a certain parent will be considered relative to the other ones included in the diallel cross (Cruz and Regazzi, 2004) for these characteristics (Rêgo et al., 2010). Taking this into consideration, the best parents with significantly positive and negative values were $77.2,132,134$, and 137.

Observing sij estimates, significantly positive and negative hybrid combinations were verified for hybrids and their reciprocals (Table 5). These results indicate the possibility of exploring hybrid vigor for the morphological characteristics that were studied in this article (Rêgo et al., 2009a).

The SCA maximum value (positive) and minimum value (negative) for fruit weight were obtained by hybrids $132 \times 134(+0.45)$ and $134 \times 137(-0.41)$. Hybrids $77.2 \times 132(+0.72)$ and $132 \times 137(-0.44)$ presented higher significant values for the fruit length trait (Table 5). Geleta and Labuschagne (2004a) and Rêgo et al. (2009a), in their studies with C. annuum and C. baccatum, respectively, also reported higher values for both characteristics, which can be explained by the different genotypes that were studied.

Only one hybrid had a significant SCA value for pedicel length, $77.2 \times 137(+0.19)$. The same was observed for the yield trait; the significant combination was $134 \times 77.1(-0.01)$, but it was negative in the reciprocal effect (Table 5). Low positive or negative $\hat{\mathrm{s}}_{\mathrm{ij}}$ estimates indicate that the behavior of a certain hybrid is determined by its parents GCA, while high absolute values indicate that some combinations are significantly better and others are worse based on the parent's GCA (Griffing, 1956; Cruz and Regazzi, 2004).

The highest significantly positive and negative values for the fruit yield per plant trait were observed in combinations of reciprocal effect: $137 \times 77.2(+6.75)$ and $77.2 \times 01(-3.91)$ (Table 5). Reciprocal effects were also important for the days to fructification characteristic; the highest significantly positive and negative values were observed in the reciprocal combinations $137 \times 77.1(+3.19)$ and $77.1 \times 01(-3.97)$ (Table 5). This last combination is of interest for precocious production.

Preference must be given to hybrid combinations that obtained significantly positive or negative values for the trait to be improved. In this case, hybrids $77.1 \times 134,132 \times 134,01$ x 132, $77.2 \times 132,77.2 \times 137$, and $132 \times 137$ are indicated.

The reciprocals $134 \times 77.2,77.1 \times 01$, and $137 \times 134$ are indicated to further the pepper breeding program. As reported by Rêgo et al. (2009a), the reciprocal effects can affect fruit characteristics in C. baccatum, which was also proved by data obtained in this paper. Such results show the importance of indicating the correct direction of crossing. 


\begin{tabular}{|c|c|c|c|c|c|c|c|c|c|c|}
\hline Accessions & $\mathrm{FW}$ & & FL & & FD & & PL & & PT & \\
\hline 01 & -0.34 & - & -0.56 & - & -0.00 & - & -0.17 & - & -0.17 & 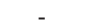 \\
\hline $01 \times 77.1(77.1 \times 01)$ & -0.01 & $(0.03)$ & -0.18 & $(-0.00)$ & 0.08 & $(0.00)$ & 0.05 & $(-0.01)$ & 0.22 & $(0.17)$ \\
\hline $01 \times 77.2(77.2 \times 01)$ & 0.09 & $(0.05)$ & -0.02 & $(-0.04)$ & 0.00 & $(0.01)$ & 0.07 & $(0.02)$ & 0.08 & $(-0.35)$ \\
\hline $01 \times 132(132 \times 01)$ & 0.12 & $(0.31)$ & 0.03 & $(0.73)$ & 0.00 & $(-0.00)$ & 0.04 & $(0.07)$ & -0.12 & $(0.02)$ \\
\hline $01 \times 134(134 \times 01)$ & 0.001 & $(-0.15)$ & -0.06 & $(-0.31)^{*}$ & 0.01 & $(-0.01)$ & 0.07 & $(-0.01)$ & -0.09 & $(0.17)$ \\
\hline $01 \times 137(137 \times 01)$ & 0.19 & $(0.09)$ & $0.47^{*}$ & $(0.19)$ & -0.01 & $(0.00)$ & -0.02 & $(0.09)$ & 0.04 & $(0.16)$ \\
\hline 77.1 & -0.00 & - & -0.10 & - & -0.01 & - & -0.07 & - & -0.09 & - \\
\hline $77.1 \times 77.2(77.2 \times 77.1)$ & -0.12 & $(0.12)$ & 0.02 & $(-0.03)$ & 0.00 & $(0.01)$ & -0.02 & $(0.10)$ & -0.03 & $(0.38)^{*}$ \\
\hline $77.1 \times 132(132 \times 77.1)$ & 0.01 & $(-0.13)$ & -0.20 & $(-0.07)$ & 0.00 & $(-0.01)$ & 0.05 & $(0.00)$ & -0.37 & $(-0.29)$ \\
\hline $77.1 \times 134(134 \times 77.1)$ & 0.30 & $(-0.06)$ & 0.27 & $(0.09)$ & 0.01 & $(-0.00)$ & 0.14 & $(-0.04)$ & $0.64^{*}$ & $(-0.03)$ \\
\hline $77.1 \times 137(137 \times 77.1)$ & 0.16 & $(0.04)$ & 0.12 & $(0.13)$ & 0.00 & $(0.00)$ & 0.05 & $(0.03)$ & -0.04 & $(-0.13)$ \\
\hline 77.2 & 0.08 & - & 0.06 & - & -0.00 & - & -0.09 & - & -0.08 & - \\
\hline $77.2 \times 132(132 \times 77.2)$ & 0.26 & $(-0.03)$ & $0.72 *$ & $(-0.19)$ & -0.00 & $(0.00)$ & 0.04 & $(0.00)$ & 0.02 & $(0.12)$ \\
\hline $77.2 \times 134(134 \times 77.2)$ & 0.10 & $(-0.19)$ & 0.005 & $(-0.06)$ & 0.00 & $(-0.02)$ & 0.02 & $(-0.03)$ & -0.02 & $(0.30)$ \\
\hline $77.2 \times 137(137 \times 77.2)$ & 0.34 & $(-0.03)$ & 0.03 & $(0.09)$ & 0.02 & $(-0.00)$ & $0.19 *$ & $(-0.00)$ & 0.28 & $(-0.38)^{*}$ \\
\hline 132 & -0.03 & - & -0.25 & - & 0.02 & - & -0.02 & - & -0.17 & - \\
\hline $132 \times 134(134 \times 132)$ & $0.45^{*}$ & $(-0.01)$ & 0.05 & $(-0.16)$ & 0.00 & $(-0.00)$ & 0.09 & $(0.01)$ & 0.22 & $(-0.19)$ \\
\hline $132 \times 137(137 \times 132)$ & -0.23 & $(-0.09)$ & $-0.44 *$ & $(-0.21)$ & -0.01 & $(-0.00)$ & -0.11 & $(-0.07)$ & -0.28 & $(0.51)^{*}$ \\
\hline 134 & 0.12 & - & 0.34 & - & 0.03 & - & 0.01 & - & -0.18 & - \\
\hline 134 x $137(137$ x 134) & $-0.41 *$ & $(0.30)$ & -0.27 & $(0.10)$ & -0.00 & $(-0.00)$ & 0.00 & $(0.04)$ & $0.44 *$ & $(-0.07)$ \\
\hline 137 & -0.31 & - & -0.31 & - & -0.00 & - & -0.09 & - & -0.08 & - \\
\hline Accessions & PLL & & FFM & & DMC & & SYF & & FYP & \\
\hline 01 & -0.25 & - & -0.24 & - & 0.49 & - & -19.28 & - & -3.75 & - \\
\hline $01 \times 77.1(77.1 \times 01)$ & 0.02 & $(0.09)$ & -0.15 & $(0.04)$ & -0.32 & $(2.06)$ & 3.83 & $(-2.28)$ & 0.00 & $(0.91)$ \\
\hline $01 \times 77.2(77.2 \times 01)$ & 0.00 & $(-0.00)$ & 0.06 & $(0.03)$ & -1.96 & $(8.55)^{*}$ & 9.83 & $(4.76)$ & -2.00 & $(-3.91)^{*}$ \\
\hline $01 \times 132(132 \times 01)$ & 0.07 & $(0.09)$ & 0.10 & $(0.21)$ & -7.33 & $(6.09)$ & 1.83 & $(10.51)$ & 0.00 & $(-3.25)^{*}$ \\
\hline $01 \times 134(134 \times 01)$ & -0.17 & $(0.00)$ & 0.03 & $(-0.15)$ & 9.90 & $(-4.75)^{*}$ & 1.50 & $(2.35)$ & 2.5 & $(-0.08)$ \\
\hline $01 \times 137(137 \times 01)$ & 0.17 & $(0.07)$ & 0.17 & $(0.10)$ & -0.77 & $(-1.76)$ & 3.93 & $(1.00)$ & 0.00 & $(3.58)^{*}$ \\
\hline 77.1 & -0.20 & - & 0.03 & - & 7.20 & - & -13.95 & - & -4.41 & - \\
\hline $77.1 \times 77.2(77.2 \times 77.1)$ & 0.07 & $(-0.01)$ & -0.07 & $(0.07)$ & 2.53 & $(-1.88)$ & -5.83 & $(1.60)$ & 3.50 & $(2.75)^{*}$ \\
\hline $77.1 \times 132(132 \times 77.1)$ & -0.08 & $(-0.19)$ & -0.01 & $(-0.17)$ & 1.71 & $(-0.45)$ & 4.0 & $(5$. & 0.00 & $(6.41)^{*}$ \\
\hline $77.1 \times 134(134 \times 77.1)$ & 0.08 & $(0.04)$ & 0.25 & $(-0.01)^{*}$ & -5.24 & $(1.58)$ & 8.33 & $(-1.64)$ & 1.00 & $(-2.91)^{*}$ \\
\hline $77.1 \times 137(137 \times 77.1)$ & -0.01 & $(0.28)$ & 0.11 & $(0.00)$ & -5.87 & $(-1.16)$ & 0.00 & $(10.76)$ & 0.00 & $(-2.75)^{*}$ \\
\hline 77.2 & 0.03 & - & 0.05 & - & 3.09 & - & 1.82 & - & - & $(-0.08)$ \\
\hline $77.2 \times 132(132 \times 77.2)$ & 0.29 & $(-0.16)$ & 0.20 & $(-0.03)$ & 6.15 & $(0.15)$ & 9.33 & $(-1.09)$ & -7.50 & $(-2.41)^{*}$ \\
\hline $77.2 \times 134(134 \times 77.2)$ & $-0.16^{*}$ & $(0.03)$ & 0.04 & $(-0.10)$ & -6.79 & $(0.83)$ & 4.50 & $(-11.09)$ & -7.50 & $(6.75)^{*}$ \\
\hline $77.2 \times 137(137 \times 77.2)$ & 0.08 & $(0.12)$ & $0.29 *$ & $(-0.02)$ & 3.17 & $(-5.07)$ & 5.16 & $(3.99)$ & $-1.50 *$ & $(-3.08)^{*}$ \\
\hline 132 & 0.78 & - & 0.04 & - & 1.47 & - & -16.67 & - & -4.75 & - \\
\hline $132 \times 134(134 \times 132)$ & -0.01 & $(-0.18)$ & $0.36^{*}$ & $(0.04)$ & -2.76 & $(0.15)$ & 2.83 & $(2.99)$ & $-2.50^{*}$ & $(-3.08)^{*}$ \\
\hline $132 \times 137(137 \times 132)$ & -0.30 & $(-0.33)$ & -0.23 & $(-0.10)$ & 0.76 & $(0.91)$ & -5.83 & $(-1.25)$ & $2.00^{*}$ & $(0.58)$ \\
\hline 134 & 0.10 & - & 0.02 & - & 6.25 & - & 12.32 & - & -1.41 & - \\
\hline $134 \times 137(137 \times 134)$ & 0.20 & $(-0.00)$ & $-0.27 *$ & $(-0.15)$ & -1.35 & $(-2.66)$ & -11.00 & $(-4.92)$ & $4.00 *$ & $(0.75)$ \\
\hline 137 & -0.14 & - & -0.15 & - & 4.04 & - & -12.50 & - & 0.91 & - \\
\hline Accessions & DTF & & $\mathrm{Y}$ & & Vit C & & TA & & TSS & \\
\hline 01 & 7.52 & - & -10.90 & - & -3.88 & - & -1.25 & - & -1.65 & - \\
\hline $01 \times 77.1(77.1 \times 01)$ & $1.50^{*}$ & $(-3.97)^{*}$ & 0.33 & $(-0.48)$ & $-6.14 *$ & $(-0.14)^{*}$ & -1.93 & $(-0.07)$ & 0.83 & $(-0.55)$ \\
\hline $01 \times 77.2(77.2 \times 01)$ & 0.00 & $(-1.55) *$ & -1.84 & $(1.12)$ & $7.25 *$ & $(0.018)$ & $2.37 *$ & $(0.00)$ & -0.44 & $(0.11)$ \\
\hline $01 \times 132(132 \times 01)$ & 0.00 & $(2.69)^{*}$ & $11.40^{*}$ & $(3.23)$ & 0.54 & $(24.86)^{*}$ & $0.14 *$ & $(7.95)$ & $1.25^{*}$ & $(-0.35)$ \\
\hline $01 \times 134(134 \times 01)$ & -1.00 & $(-0.88)$ & -3.01 & $(1.90)$ & 0.56 & $(26.07) *$ & 0.17 & $(8.3$ & -0.36 & $(-1.30)^{*}$ \\
\hline $01 \times 137(137 \times 01)$ & $-2.00 *$ & $(-3.80) *$ & 4.03 & $(6.49)$ & $1.65^{*}$ & $(28.74) *$ & 0.49 & $(9.16) *$ & 0.37 & $(-0.53)$ \\
\hline 77.1 & 0.52 & - & -2.01 & - & -7.16 & - & -2.14 & - & 0.95 & - \\
\hline $77.1 \times 77.2(77.2 \times 77.1)$ & -1.00 & $(-1.55)^{*}$ & 3.63 & $(-3.72)$ & $13.29^{*}$ & $(-2.61)^{*}$ & $4.07 *$ & $(-1.11)$ & -0.77 & $(-0.55)$ \\
\hline $77.1 \times 132(132 \times 77.1)$ & 0.50 & $(0.19)$ & 1.01 & $(0.37)$ & -0.73 & $(25.52)^{*}$ & -0.18 & $(8.21)^{*}$ & $-1.67 *$ & $(-0.08)$ \\
\hline $77.1 \times 134(134 \times 77.1)$ & $-1.50 *$ & $(1.61)^{*}$ & -2.01 & $(6.08)$ & -0.89 & $(26.36)^{*}$ & -0.28 & $(8.41)^{*}$ & 0.59 & $(-1.88)^{*}$ \\
\hline $77.1 \times 137(137 \times 77.1)$ & -1.00 & $(3.19)^{*}$ & -0.95 & $(4.04)$ & $1.64 *$ & $(30.38) *$ & 0.47 & $(9.63) *$ & 0.06 & $(-0.41)$ \\
\hline 77.2 & 3.36 & - & 1.05 & - & 18.89 & - & 6.06 & - & -0.26 & - \\
\hline $77.2 \times 132(132 \times 77.2)$ & 0.00 & $(-3.38) *$ & -1.36 & $(0.51)$ & $-12.63^{*}$ & $(1.31)^{*}$ & $-4.02 *$ & $(0.41)$ & -0.08 & $(0.45)$ \\
\hline $77.2 \times 134(134 \times 77.2)$ & 0.00 & $(2.02)^{*}$ & -0.02 & $(-0.3)$ & $-12.86^{*}$ & $(1.91)^{*}$ & $-4.08 *$ & $(0.61)$ & 1.09 & $(-0.60)$ \\
\hline $77.2 \times 137(137 \times 77.2)$ & 0.00 & $(1.11)$ & -1.45 & $(6.38)$ & $-13.95^{*}$ & $(2.22)^{*}$ & $-4.41 *$ & $(0.71)$ & 0.47 & $(0.96)$ \\
\hline 132 & -0.13 & - & -6.02 & - & 4.58 & - & 1.43 & - & -0.47 & - \\
\hline $132 \times 134(134 \times 132)$ & 0.00 & $(2.27)^{*}$ & -3.69 & $(4.57)$ & $4.58 *$ & $(0.68)$ & $1.44 *$ & $(0.21)$ & 0.49 & $(-0.56)$ \\
\hline $132 \times 137(137 \times 132)$ & 0.00 & $(-1.63)^{*}$ & -1.33 & $(-1.73)$ & $3.65 *$ & (1.07) & 1.16 & $(0.34)$ & 0.49 & $(0.00)$ \\
\hline 134 & -2.30 & - & 2.81 & - & 4.71 & - & 1.49 & - & -0.90 & - \\
\hline $134 \times 137(137 \times 134)$ & $0.50 *$ & $(-2.72)$ & 5.93 & $(-1.92)$ & & $(0.41)$ & $1.25^{*}$ & $(0.13)$ & -0.91 & $(1.48)^{*}$ \\
\hline 137 & 3.86 & - & -6.21 & - & 3.11 & - & 1.02 & - & -0.49 & - \\
\hline
\end{tabular}

$\mathrm{FW}=$ fruit weight $(\mathrm{g}) ; \mathrm{FL}=$ fruit length $(\mathrm{cm}) ; \mathrm{FD}=$ fruit diameter $(\mathrm{cm}) ; \mathrm{PL}=$ pedicel length $(\mathrm{cm}) ; \mathrm{PT}=$ pericarp thickness $(\mathrm{cm}) ;$ PLL $=$ placenta length $(\mathrm{cm}) ; \mathrm{FFM}=$ fresh fruit matter $(\mathrm{g}) ; \mathrm{DMC}=$ dry matter content $(\mathrm{g}) ; \mathrm{SYF}$ $=$ seed yield per fruit; FYP = fruit yield per plant; DTF = days to fructification; $\mathrm{Y}=$ yield $(\mathrm{g})$; Vit $\mathrm{C}=$ vitamin $\mathrm{C}$ $\left(\mathrm{mg}\right.$ ascorbic acid/100 g); TA = titratable acidity ( $\mathrm{g}$ citric acid/100 $\mathrm{g}$ fresh fruit); TSS = total soluble solids $\left({ }^{\circ}\right.$ Brix $)$. *Significant at $5 \%$ probability by the $t$-test. 


\section{Fruit quality characteristics}

The mean squares associated with GCA, SCA, and the reciprocal effect were significant at $1 \%$ probability by the F-test for all quality characteristics except placenta length, in which the reciprocal effects were not identified (Table 3 ).

The highest $\hat{\phi}_{g}^{2}$ values indicate a predominance of additive gene effects for the placenta length, vitamin $\mathrm{C}$, and titratable acidity traits, as shown by the GCA/SCA ratio (Table 3).

There was a predominance of non-additive gene effects for the characteristics dry matter content and total soluble solids. According to Lannes et al. (2007), the total soluble solids content and the dry matter content are highly correlated and can be used effectively in Capsicum breeding programs for the production of spice-market-oriented cultivars.

Additive effects controlled the expression of the placenta length characteristic. The findings of this report agree with those Marin and Lippert (1975) working with pepper $(C$. annuum L.) and Zewdie and Bosland (2001) working with pungency in C. pubescens. For vitamin $\mathrm{C}$ and acidity, a greater magnitude of additive genetic effects controlling the traits was observed. Similar observations were made by Schuelter et al. (2010).

Non-additive gene effects were predominant in the characteristic total soluble solids. Similar results were obtained by Rêgo et al. (2009a). A greater magnitude of non-additive effects, epistasis and/or dominance, were also observed to control dry matter content. The opposite was reported by Marin and Lippert (1975), Ahmed et al. (1999), Geleta and Labuschagne (2004a), and Rêgo et al. (2009a), who observed a higher magnitude of additive effects for this trait.

The $\hat{g} i$ estimates based on GCA indicate that genitor 132 had a high positive significant value for the placenta length characteristic. Parent 77.2 had a significantly negative value, which is not of interest (Table 4). The placenta length characteristic is extremely important because the highest amounts of capsaicinoids are found in the placenta (Zewdie and Bosland, 2001).

Significant $g i$ values were observed for the vitamin $C$ and acidity traits. In both cases, genitors $01,77.1$, and 77.2 presented significantly positive values. This is of interest for crossings with the goal of increasing the nutritional quality in pepper. The other parents, 132, 134, and 137 , presented significantly low values both for vitamin $\mathrm{C}$ and acidity.

Significantly positive gi values were observed for dry matter content in genitors 77.1 and 134. Values with negative significance were obtained for parents $77.1,132$, and 137 (Table 4). Dry matter is important to the industry because a large amount of pepper produced in the world is used in the form of powder (Sousa and Maluf, 2003).

For the characteristic total soluble solids, only the genitor 77.1 had a significant value; however, it is not of interest because its significance was negative, and the goal of the program is to increase this trait. According to Lannes et al. (2007), this characteristic is very important in the cultivation of Capsicum for industrial purposes. Commercial cultivars and hybrids with high content of soluble solids would reduce the production cost of food colorants because they contain less water to be removed during drying, moreover decreasing the contamination by fungal and bacterial pathogens.

Significantly positive and negative hybrids were verified for all evaluated quality characteristics (Table 5).

For placenta length, the only significant hybrid combination was $77.2 \times 134(-0.16)$, which was negative (Table 5) and can be used to select less pungent plants.

The highest positive and negative SCA values for vitamin C were found in the recip- 
rocals $137 \times 77.1(+30.38)$ and $137 \times 77.2(-13.95)$ (Table 5). According to Carvalho (1984), the vitamin $\mathrm{C}$ content found in pepper is higher than that in oranges, with $60 \mathrm{mg}$ per $100 \mathrm{~g}$ pulp, equaling the content found in guava and acerola. This amount is the recommended daily vitamin C dose (Rêgo et al., 2012), and it is of interest to select combinations that are positive for this trait.

Reciprocal effects were also significant for the acidity characteristic, and the highest values were observed in the $137 \times 77.1(+9.63)$ and $77.2 \times 137(-4.41)$ combinations (Table $5)$. The acidity control in conserved products is important in order to prevent the growth of Clostridium botulinum (Gardner, 1973; Figueiredo, 2004). In addition to being an important parameter to appreciate the conservation state of a food product (Oliveira et al., 1998), this characteristic can be affected by the way it is harvested, damages sustained in handling and storage, and maturation stages.

The reciprocal combinations that had the highest positive and negative significances for total soluble solids were $137 \times 134(+1.48)$ and $134 \times 77.1(-1.88)$ (Table 5). For this trait, significantly positive values are of interest.

Overall, for the purposes of improving characteristics related to the quality of pepper plants (C. annuum), genitors 01 and 77.2 stood out, revealing an elevated genetic potential to transfer favorable alleles to better the population's performance in these characteristics (Cruz and Regazzi, 2004).

The SCA effects stress the importance of non-additive interactions resulting from the gene complementation between parents, enabling the prediction of genetic gain responses through the exploration of heterosis (Bastos et al., 2003; Rêgo et al., 2009a). The hybrids indicated for breeding quality characteristics are 137 x 77.1 and 137 x 134 .

\section{CONCLUSION}

The results obtained here clearly show that pepper varieties can be developed through hybridization in a $C$. annuum breeding program. For characteristics that presented non-additive gene effects, epistasis and/or dominance, such as pericarp thickness, fresh matter, pedicel length, seed yield per fruit, number of fruits per plant, days to fructification, and total soluble solids, the production of hybrids is indicated as the best strategy.

GCA effects were the most important to fruit weight, fruit length and diameter, placenta length, yield, vitamin $\mathrm{C}$, and acidity variables. For these traits, massal, pedigree, or bulk selection can be applied.

Based on the gi and sij values, to continue the ornamental pepper (C. annuиm) breeding program, the selection of genitors $01,132,77.2$, and 137 is indicated, as well as the selection of the $132 \times 134,01 \times 132,137 \times 134,77.2 \times 137,137 \times 77.1,77.1 \times 01$, and $134 \times 77.2$ families. These can be used to further the segregating generation analysis in the $C$. annuиm breeding program with the goal of increasing yield per plant, and to obtain fruits with large amounts of pulp and placenta, high fresh and dry matter, and high nutritional values.

\section{ACKNOWLEDGMENTS}

The authors thank the Coordination for the Improvement of Higher Level or Education Personnel (CAPES) and the National Counsel of Technological and Scientific Development $(\mathrm{CNPq})$ for financial support and fellowship. 


\section{REFERENCES}

Ahmed N, Khan SH and Tanki MI (1997). Combining ability analysis for fruit yield and its component characters in sweet pepper studies in hot pepper (Capsicum annuum L.). Capsicum Eggplant Newsl. 16: 72-75.

Ahmed N, Tanki MI and Jabeen N (1999). Heterosis and combining ability studies in hot pepper (Capsicum annuum L.). Appl. Biol. Res. 1: 11-14.

Bastos IT, Barbosa MHP, Cruz CD and Burnquist WL (2003). Análise dialélica em clones de cana-de-açúcar. Bragantia 62: 199-206.

Ben-Chaim A and Paran I (2000). Genetic analysis of quantitative traits in pepper (Capsicum annuum). J. Am. Soc. Hort. Sci. 125: 66-70.

Carvalho VD (1984). Características químicas de pimentões e pimentas. Agropecuário 10: 76-78.

Casali VW and Couto FAA (1984). Origem e botânica de Capsicum. Inf. Agropecuário 10: 8-10.

Cruz CD (2006). Programa Genes (versão Windows): Aplicativo Computacional em Genética e Estatística. Editora UFV (Universidade Federal de Viçosa), Viçosa.

Cruz CD and Regazzi AJ (2001). Modelos Biométricos Aplicados ao Melhoramento Genético. Imprensa Univérsitária, Viçosa.

Cruz CD and Regazzi AJ (2004). Modelos Biométricos Aplicados ao Melhoramento Genético. 3rd edn. Imprensa Univérsitária, Viçosa.

Doshi KM and Shukla PT (2000). Combining ability analysis for fresh fruit yield and its components over environments in chili (Capsicum annuum). Capsicum Eggplant Newsl. 19: 82-85.

Figueiredo RM (2004). Produção e Processamento de Pimenta. Centro de Produções Técnicas, Viçosa.

Gardner WH (1973). Acidulants in Food Processing. In: Handbook of Food Additives (Furia TE, eds.). CRC Press, Cleveland.

Geleta LF and Labuschagne MT (2004a). Comparative performance and heterosis in single, three-way and double cross pepper hybrids. J. Agric. Sci. 142: 659-663.

Geleta LF and Labuschagne MT (2004b). Hybrid performance for yield and other characteristics in peppers (Capsicum annuит L.). J. Agric. Sci. 142: 411-419.

Gomide ML, Maluf WR and Gomes LAA (2008). Capacidade de combinação em linhagens elites de pimentão (Capsicum annuum L.). Ciênc. Agrot. 32: 740-748.

Gonçalves LSA, Rodrigues R, Bento CS, Robaina RR, et al. (2011). Herança de caracteres relacionados à produção de frutos em Capsicum baccatum var. pendulum com base em análise dialélica de Hayman. Rev. Ciênc. Agron. 42: $662-669$.

Griffing B (1956). Concept of general and specific combining ability in relation to diallel crossing systems. Aust. J. Biol. Sci. 9: 463-493.

Heiden G, Barbieri RL, Couto MEO and Medeiros ARM (2007). Pimentas e Pimentões do Sul do Brasil: Variedades Crioulas Mantidas pela Embrapa Clima Temperado. Anais do $2^{\circ}$ Congresso Brasileiro de Agroecologia, Porto Alegre. International Plant Genetic Resources Institute (1995). Descriptores for Capsicum (Capsicum spp). IPGRI, Roma.

Kamble C, Mulge RM and Madalageri B (2009). Combining ability for earliness and productivity in sweet pepper (Capsicum annuum L.). Karnataka J. Agric. Sci. 22: 151-154.

Lannes SD, Finger FL, Schuelter AR and Casali VWD (2007). Growth and quality of Brazilian accessions of Capsicum chinense fruits. Sci. Hortic. 112: 266-270.

Marame F, Dessalegne L, Fininsa C and Sigvald R (2009). Heterosis and heritability in crosses among Asian and Ethiopian parents of hot pepper genotypes. Euphytica 168: 265-247.

Marin O and Lippert LF (1975). Combining ability analysis of anatomical components of the dry fruit in chili pepper. Crop. Sci. 15: 326-329.

Nascimento NFF, Rêgo ER, Rêgo MM, Nascimento MF, et al. (2012). Compatibilidade em cruzamentos intra e interespecíficos em pimenteiras ornamentais. Rev. Bras. Hortic. Orn. 18: 57-61.

Oliveira VR, Scapim CA and Casali VWD (1998). Diversidade genética e eficiência da predição do comportamento de híbridos de pimentão de híbridos de pimentão (Capsicum annuum L.). Acta Sci. 20: 263-267.

Patel JA, Shukla MR, Doshi KN, Patel BR, et al. (1988). Combining ability for green fruit and components in chilli (Capsicum annuum L.). Capsicum Eggplant Newsl. 17: 34-37.

Pickersgill B (1997). Genetic resources and breeding of Capsicum spp. Euphytica 96: 129-133.

Poulos JM (1994). Pepper breeding (Capsicum spp.): achievements, challenges and possibilities. Plant Breed. 64: 143-155.

Reddy MG, Kumar HDM and Salimath PM (2008). Combining ability analysis in chilli (Capsicum annuum L.). Karnataka J. Agric. 21: 494-497.

Rêgo ER, Rêgo MM, Finger FL, Cruz CD, et al. (2009a). A diallel study of yield components and fruit quality in chilli pepper (Capsicum baccatum). Euphytica 168: 275-287. 
Rêgo ER, Rêgo MM, Silva DF, Cortez RM, et al. (2009b). Selection for leaf and plant size and longevity of ornamental peppers (Capsicum spp.) grown in greenhouse condition. Acta Hort. 829: 371-375.

Rêgo ER, Rêgo MM, Cruz CD and Finger FL (2010). Phenotypic diversity, correlation and importance of variables for fruit quality and yield traits in Brazilian peppers (Capsicum baccatum). Genet. Resour. Crop Evol. 58: 909-918.

Rêgo ER, Finger FL, Nascimento NFF and Araújo ER (2011a). Genética e Melhoramento de Pimenteiras. In: Produção, Genética e Melhoramento de Pimentas (Capsicum spp.) (Rêgo ER, Finger FL and Rêgo MM, eds.). Imprima, Recife, 117-136.

Rêgo ER, Finger FL, Nascimento MF and Barbosa LAB (2011b). Pimenteiras Ornamentais. In: Produção, Genética e Melhoramento de Pimentas (Capsicum spp.) (Rêgo ER, Finger FL and Rêgo MM, eds.). Imprima, Recife, 205-223.

Rêgo ER, Finger FL and Rêgo MM (2012). Consumption of Pepper in Brazil and its Implications on Nutrition and Health of Humans and Animals. In: Pepper: Nutrition, Consumption and Health (Salazar MA and Ortega JM, eds.). Science Publishers, New York, 159-170.

Schuelter AR, Pereira GM, Amaral AT Jr, Casali VW, et al. (2010). Genetic control of agronomically important traits of pepper fruits analyzed by Hayman's partial diallel cross scheme. Genet. Mol. Res. 9: 113-127.

Somashekhar SAP and Salimath PM (2008). Estimation of gene effects for fruit yield and its components in chilli (Capsicum annuum L.). Karnataka J. Agric. Sci. 21: 181-183.

Sousa JA and Maluf WR (2003). Diallel analyses and estimation of genetic parameters of hot pepper (Capsicum chinense Jacq). Sci. Agric. 60: 105-113.

Sudré CP, Rodrigues R, Riva EM, Karasawa M, et al. (2005). Divergência genética entre acessos de pimenta e pimentão utilizando técnicas multivariadas. Hort. Bras. 23: 22-27.

Zambrano GM, Gonzalez JRA, Meraz MR and Loera AR (2005). Efectos geneticos y heterosis em la vida de anaquel del Chile serrano. Rev. Fitotec. Mex. 28: 327-332.

Zewdie Y and Bosland PW (2000). Capsaicinoid inheritance in an interspecific hybridization of Capsicum annuum x C. chinense. J. Am. Soc. Hort. Sci. 125: 448-453.

Zewdie Y and Bosland PW (2001). Combining ability and heterosis for capsaicinoids in Capsicum pubescens. Hort. Sci. 36: 1315-1317. 